\title{
Small Renal Mass with Sarcomatoid Features
}

\author{
Anthony D. Oberle James A. Brown \\ Department of Urology, University of lowa Hospitals and Clinics, lowa City, IA, USA
}

\section{Key Words}

Metastasis • Renal cell carcinoma • Sarcomatoid

\begin{abstract}
Interest in surveillance for small renal masses has expanded exponentially due to incidental detection with increased imaging. However, some of these small renal masses behave aggressively. Sarcomatoid pathology is associated with a worse prognosis. Traditionally, it has been thought of as a common pathway of dedifferentiation once a renal malignancy of any histology reaches a threshold size of approximately $3 \mathrm{~cm}$. We report a case of a 65 -year-old male with a $2 \mathrm{~cm}$ sarcomatoid renal cell carcinoma. To our knowledge, this is the smallest tumor with sarcomatoid differentiation reported in the literature.

(c) 2020 The Author(s)

Published by S. Karger AG, Basel
\end{abstract}

\section{Introduction}

The incidence of small renal masses measuring $\leq 4$ $\mathrm{cm}$ have increased over time and the interest in surveillance of these small renal masses has also increased [1, 2]. Many studies have evaluated outcomes of active surveillance compared to primary intervention and found no difference in survival [3]. However, we do know that some small renal masses behave aggressively. Even some masses measuring $<1 \mathrm{~cm}$ have been reported as metastatic [4]. It is unclear exactly what factors lead to

\section{KARGER}

Fax +4161306 1234

E-Mail karger@karger.com

www.karger.com
(C) 2020 The Author(s) Upen access

This article is licensed under the Creative Commons AttributionNonCommercial-NoDerivatives 4.0 International License (CC BYNC-ND) (http://www.karger.com/Services/OpenAccessLicense) Usage and distribution for commercial purposes as well as any distribution of modified material requires written permission. metastatic spread of small renal masses. Sarcomatoid pathology is particularly noted with aggressive disease and a poor prognosis [5]. The incidence of sarcomatoid dedifferentiation in renal cell carcinomas is estimated at approximately $5 \%$. The majority of tumors with sarcomatoid differentiation are large and represent an end stage of renal cell carcinoma dedifferentiation [6]. Sarcomatoid is no longer recognized as a distinct subtype of renal cell carcinoma. It is a poorly differentiated area within one of the known subtypes. We present a case of a 65 -year-old male with a $2.0 \mathrm{~cm}$ renal mass with retroperitoneal metastasis that upon removal was found to contain sarcomatoid elements.

\section{Case Report}

A 65-year-old male presented to the emergency department with a short history of abdominal and low back pain. An initial CT of the chest, abdomen, and pelvis with IV contrast was obtained by the emergency room physicians due to the pain. A multi lobulated mass measuring $8.2 \times 8.5 \times 8.3 \mathrm{~cm}$ was seen in the retroperitoneum (fig. 1, 2). There was no discernable renal tumor on imaging. MRI was obtained which did not show any direct extension from the retroperitoneal mass to the kidney. Core biopsies were obtained which returned, malignant epithelioid neoplasm, most consistent with renal cell carcinoma. The cells from the retroperitoneal mass stained positive for pancytokeratin and PAX8, and negative for S100, SOX10, SMSA, and Desmin.

At this point the patient was referred to our urology service. No primary tumor was observed in the kidney. Multi-disciplinary discussion of the patient was performed among urology, medical-oncology, radiology, and pathology. Decision was made to 


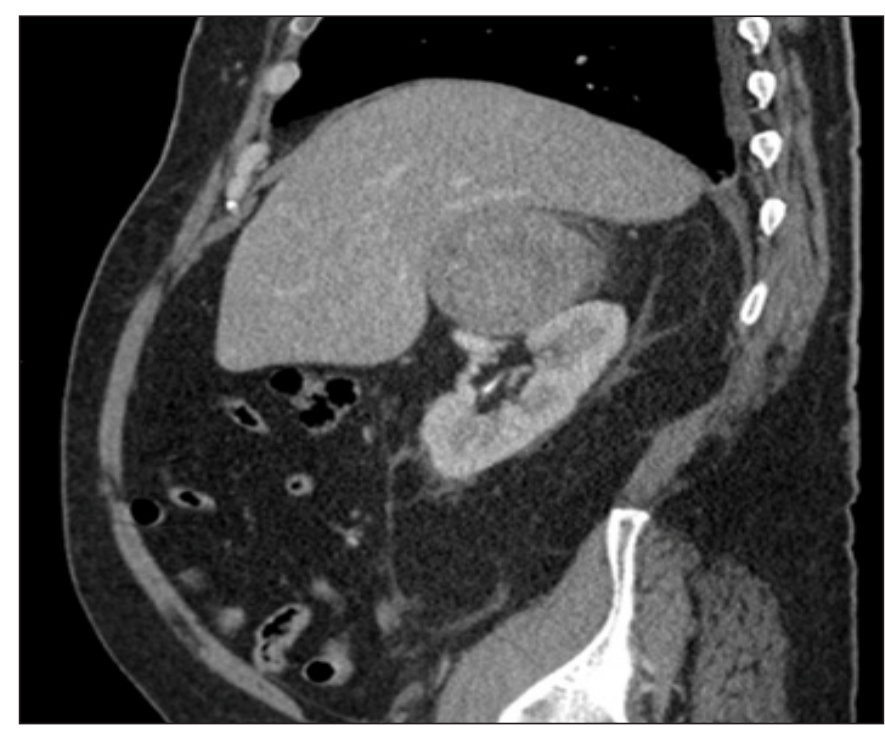

Fig. 1. Sagittal CT with IV contrast, obtained at presentation showing mass near kidney but not directly extending from kidney.

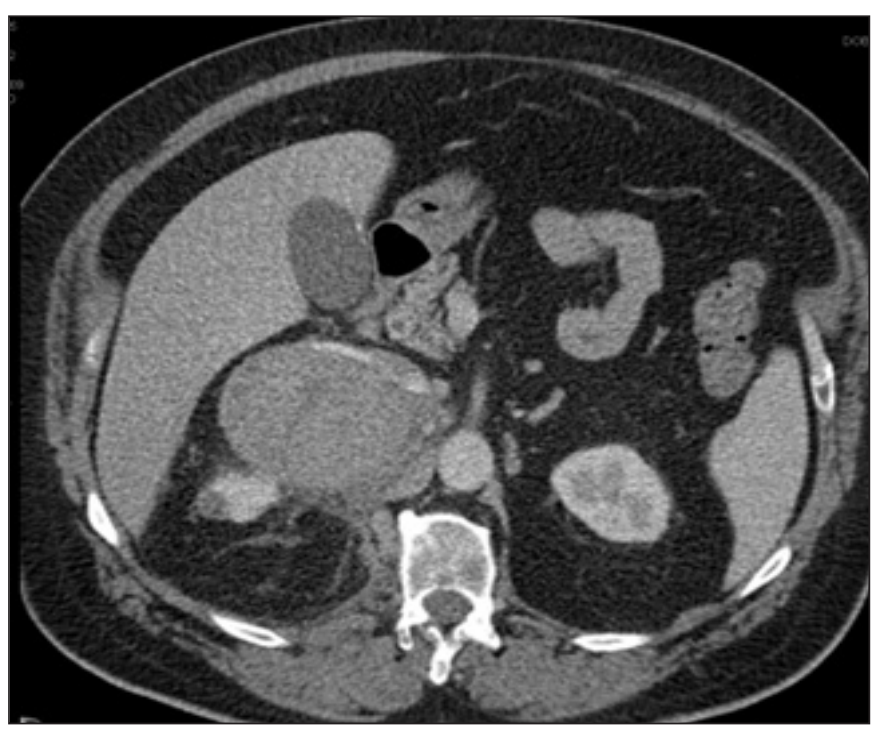

Fig. 2. Axial CT with IV contrast showing superior pole of right kidney with small renal mass closely associated with a cyst. Large retroperitoneal mass is also visible. proceed with a retroperitoneal mass resection and a right nephrectomy. Nephrectomy was undertaken due to the close nature of the 8 -cm lymph node with biopsy proven renal cell carcinoma. Procedure was uncomplicated. Retroperitoneal mass was noted to not grossly involve the kidney.

Initial gross examination of the kidney revealed no abnormality. Pathologic reexamination with additional sectioning identified a $2.0 \mathrm{~cm}$ mass in the superior pole of the kidney with extension into the adjacent perirenal fat. Intra-renal tumor was noted to be separate from the retroperitoneal mass. Perinephric lymph nodes were evaluated and 4/5 contained metastatic carcinoma including the largest which was the previously identified retroperitoneal mass. The adrenal gland was noted to contain a focal invasion of tumor from the largest lymph node. Pathologic stage was T3aN1 as tumor invaded perirenal fat, adrenal gland involvement was extension from one of the regional lymph nodes. Histologic grade was World Health Organization Grade 4 out of 4 with sarcomatoid features.

Due to his advanced disease, at 3-months post-surgery, he was initially started on cabozantinib which he has largely remained on for the past 9 months. The patient's most recent follow-up imaging at 12-month follow-up, was a CT chest, abdomen, and pelvis revealing no evidence of disease.

\section{Discussion}

To our knowledge, we report the smallest renal cell carcinoma with sarcomatoid features in the literature. Small renal masses have received increased attention as

Small Renal Mass with Sarcomatoid Features widespread use of imaging has resulted in a stage shift for renal cell carcinoma. We present this case for 2 purposes. First, the importance of close surveillance of small renal masses. Even a mass that was not clearly visible on CT scan resulted in sarcomatoid dedifferentiation and metastatic disease. Second, even in very aggressive disease surgical resection coupled with systemic chemotherapy can result in a complete response for at least a year.

The AUA guidelines are clear that patients with small renal masses should be counseled about the potential risk of cancer progression [7]. While guidelines are provided for localized renal cancer, there is a paucity of guidelines for the management of metastatic renal cell carcinoma in the targeted therapy era. There is agreement that candidates for cytoreductive nephrectomy should have excellent performance status and no brain metastasis [8]. The role for cytoreductive nephrectomy in the targeted therapy era remains based largely on level one evidence regarding the benefit of radical nephrectomy prior to interferon therapy [9]. This case emphasizes the potential value of cytoreductive nephrectomy and complete metastasectomy in the era of targeted therapy.

Our patient's presentation is also unusual in that his primary tumor was much smaller than his metastatic burden. While we understand the benefit of cytoreductive nephrectomy is less clear in this setting, our patient's 
year-long disease free status despite sarcomatoid features supports the potential benefit of nephrectomy plus metastasectomy in appropriate surgical candidates when feasible [2]. However, further research to better define which small renal masses can be safely observed is needed.

\section{References}

-1 de Peralta-Venturina M, Moch H, Amin M, Tamboli P, Hailemariam S, Mihatsch M, Javidan J, Stricker H, Ro JY, Amin MB: Sarcomatoid differentiation in renal cell carcinoma: a study of 101 cases. Am J Surg Pathol 2001;25:275-284.

$\checkmark 2$ Cheville JC, Lohse CM, Zincke H, Weaver AL, Leibovich BC, Frank I, Blute ML: Sarcomatoid renal cell carcinoma: an examination of underlying histologic subtype and an analysis of associations with patient outcome. Am J Surg Pathol 2004;28:435-441.

$\checkmark 3$ Pierorazio PM, Johnson MH, Ball MW, Gorin MA, Trock BJ, Chang P, Wagner AA, McKiernan JM, Allaf ME: Five-year analysis of a multi-institutional prospective clinical trial of delayed intervention and surveillance for small renal masses: the DISSRM registry. Eur Urol 2015;68:408-415.
4 Nguyen MM, Gill IS: Effect of renal cancer size on the prevalence of metastasis at diagnosis and mortality. J Urol 2009; 181:1020-1027.

5 Wein AJ, Kavoussi LR, Novick AC, Partin AW, Peters CA: Campbell-Walsh urology, ed 10. Philadelphia, Elsevier Saunders, 2012.

6 Jones TD, Eble JN, Wang M, Maclennan GT, Jain S, Cheng L: Clonal divergence and genetic heterogeneity in clear cell renal cell carcinomas with sarcomatoid transformation. Cancer 2005;104:1195-1203.

7 Campbell S, Uzzo RG, Allaf ME, Bass EB, Cadeddu JA, Chang A, Clark PE, Davis BJ, Derweesh IH, Giambarresi L, Gervais DA, Hu SL, Lane BR, Leibovich BC, Pierorazio PM: Renal mass and localized renal cancer: AUA Guideline. J Urol 2017;198:520-529.
Motzer RJ, Jonasch E, Agarwal N, Bhayani S, Bro WP, Chang SS, Choueiri TK, Costello BA, Derweesh IH, Fishman M, Gallagher TH, Gore JL, Hancock SL, Harrison MR, Kim W, Kyriakopoulos C, LaGrange C, Lam ET, Lau C, Michaelson MD, Olencki T, Pierorazio PM, Plimack ER, Redman BG, Shuch B, Somer B, Sonpavde G, Sosman J, Dwyer M, Kumar R: Kidney cancer, version 2.2017, NCCN clinical practice guidelines in oncology. J Natl Compr Canc Netw 2017; 15:804-834.

9 Flanigan RC, Salmon SE, Blumenstein BA, Bearman SI, Roy V, McGrath PC, Caton JR Jr, Munshi N, Crawford ED: Nephrectomy followed by interferon alfa-2b compared with interferon alfa-2b alone for metastatic renal-cell cancer. N Engl J Med 2001;345:1655-1659. 